\title{
Contagion, counterterrorism and criminology: The Case of France
}

Criminology \& Criminal Justice 2018, Vol. 18(5) 568-584

(C) The Author(s) 2018

Article reuse guidelines: sagepub.com/journals-permissions DOI: $10.1177 / 1748895817751829$ journals.sagepub.com/home/crj

@SAGE

\section{Claire Hamilton}

Maynooth University, Ireland

\section{Giulia Berlusconi}

University of Surrey, UK

\begin{abstract}
In the burgeoning criminological literature on security, risk and preventive justice which has followed the $9 / 11$ attacks on the Twin Towers, 'contagion' or the deleterious effect of counterterrorist policies on the ordinary criminal law has been the subject of some discussion, mostly in the context of the threat which such 'exceptional' policies pose to mainstream procedural values. This article seeks to build on this literature through an examination of the impact of post $9 / 11$ counterterrorism law and policy on the ordinary criminal justice system in France. Given the extent to which counterterrorist law now encroaches on various aspects of French criminal law, the argument is made for greater criminological attention to be paid to the 'trickle-down' effect of extraordinary law on the ordinary business of the criminal justice system.
\end{abstract}

\section{Keywords}

Contagion, counterterrorism, criminal justice, criminology, France

\section{Introduction}

Coming from its historical position as a discipline of the Westphalian nation state or 'discipline of the inside' as Loader and Percy (2012) would have it, mainstream criminology traditionally has been reluctant to engage with the terrorism field, terrorism and

\section{Corresponding author:}

Claire Hamilton, Senior Lecturer in Law, Department of Law, New House, South Campus, Maynooth University, Co. Kildare, Ireland.

Email: claire.hamilton@mu.ie 
warfare being seen as more properly the domain of international relations or critical security studies scholars (Aas, 2013). Notwithstanding much important work on the political construction and regulation of the 'new terrorism' (Mythen and Walklate, 2006; Walklate and Mythen, 2014) and a growing literature on the aetiology of terrorism (e.g. LaFree and Freilich, 2016), this absence has been particularly keenly felt in the counterterrorism area (Deflem, 2009: 538). Observing this lacuna, and calling for a general criminological theory of security, Zedner (2007a: 264) has argued that 'the temporal shift denoted by the war on terror poses a powerful challenge to the historic precincts of criminological scholarship. Where once terrorism and counter terrorism stood outside the normal boundaries of criminological knowledge, they now demand criminological attention.' Couched within her broader arguments about the limitations of criminological nationalism, Aas (2013) too has highlighted the transformative potential of transnational threats such as terrorism for the governance of national security and justice issues, particularly in the context of a seemingly permanent 'war' on terror. In similar vein, Aradau and Van Munster (2009) urge criminology to engage with the Schmittian theory of exceptionalism, more commonly the preserve of the international relations field, in order to better understand the significance of the 'international' and the role of the exception in underwriting, rather than overwriting, the law. For them, viewing counterterrorism law through the lens of exceptionalism allows a focus on the manner in which such exceptional politics of fear 'feed back into society' thereby 'integrat[ing] the everyday mundane practices of policing with the exceptional practices of war' (Aradau and Van Munster, 2009: 698).

From this somewhat slow starting point, however, criminology has moved incrementally to engage with counterterrorism law and policy. Ericson's (2007) work on 'counterlaw' is a case in point, employing the twin monikers of 'Counter law 1' (laws that undermine other laws) and 'Counter law 2' (extra-legal surveillance) to capture the multiple forms of governance spawned by the security state. This work has in turn strongly informed the pioneering research of Murphy (2012) on the impact of the vast body of EU counterterrorism law, and particularly its implications for fundamental rights and the rule of law. As averred to above, scholars such as Ashworth (Ashworth and Zedner, 2014) and Zedner (2007a, 2007b, 2014) have also been active in debating the criminological implications of more general shifts from a 'post- to a pre-crime society' and, correspondingly, from criminal justice to security. Defining 'pre-crime' measures as those which permit the state to intervene and restrain an individual on the basis of anticipated harm rather than past wrongdoing, the relevance to (now familiar) counterterrorism measures such as control orders/terrorism prevention and investigation measures (TPIMs) and the criminalization of association and preparatory offences is evident. Indeed, it is clear that the catastrophic risks posed by terrorism post $9 / 11$, and the concomitant pressure to action, have acted as a significant spur to pre-emptive governmental action in the field of crime control more generally (Zedner, 2007b). This new security/justice landscape, with its blurring of familiar distinctions between politics and justice, war and crime, evidence and intelligence, is only beginning to be negotiated by criminologists in the past decade (Aas, 2012; McCulloch and Pickering, 2009).

Implicit within much of this work is a concern for the normalizing impulses of counterterrorist law, and thus its migration to other substantive domains. While recognizing 
that 'many elements of the post-crime criminal justice framework continue to exist', McCulloch and Pickering (2009: 641), for example, speak of pre-crime demarking a 'new frontline so that law is always catching up with the reality of policing'. Zedner (2007b: 201) voices similar concerns for the protection of established procedural rights, citing the use of the special advocate procedure, first pioneered as a response to national security concerns in immigration hearings, and subsequently 'infiltrat[ing] ... the mainstream criminal process at alarming speed.' Further threats to the integrity of the criminal process involving a substantial expansion of criminal liability, threats to the trial and the principle of proportionate punishment are identified in later work which colourfully speaks of criminal law itself being 'terrorized' by supposedly 'exceptional' amendments to criminal law and procedure introduced in the name of counterterrorism (Zedner, 2014). Zedner's arguments in this regard are thought-provoking: might we be premature in celebrating the (partial) return in US counterterrorism law to a criminal justice model? Are there risks inherent in recourse to the criminal law when it comes to terrorism?

It is the aim of this article to support and develop these arguments through an elaboration of the various ways in which 'exceptional' criminal justice measures introduced to combat terrorism in France have come to be applied more widely, including in other areas of the criminal law, viz. 'the contagion thesis'. While many different labels have been applied to describe this phenomenon, among them normalization (Kilcommins and Vaughan, 2004), creep (Appleby and Williams, 2010), contamination (Fenwick and Phillipson, 2011) and transplantation (Donohue, 2012), contagion appeared to us the most appropriate term given the seriousness with which it conveyed the threat to the ordinary criminal justice system. A medical metaphor with its obvious connotations for public health also appeared to us to communicate more effectively the risks associated with the spread of policies not only in time (in terms of temporary legislation becoming permanent), but also cross-sectorally. From this perspective, France appears particularly appropriate as a case study as a jurisdiction with long experience of terrorism but also one which since the 1950s has expressly rejected the adoption of (non-criminal) special measures to fight terrorism, preferring instead to adapt its ordinary criminal law and procedure (Cahn, 2010; Shapiro, 2010). While recent events have obviously led to the declaration of a formal state of emergency, the fact that the adaptation of the ordinary criminal law (and corresponding absence of exceptional legislation) can probably be regarded as the traditional hallmark of the French counterterrorist system (Cahn, 2010; Hellmuth, 2015) makes it an ideal candidate for scrutiny with regard to the impact of counterterrorist legislation on the mainstream system. Detailed below are three ways in which we argue that French counterterrorist law, spanning September 2001 to June 2016, has impacted the ordinary criminal realm. Methods drawn on include: legal analysis of French counterterrorist legislation, including review of related legal and criminological literature, official reports, books and reports by experts and non-governmental organizations (NGOs) (e.g. Amnesty International) and historical newspaper reports. Where relevant these findings are supplemented by interviews conducted with French academics and civil society representatives. The final section of the article moves from this analysis to conclude that a contagion effect occurs through a variety of subtle mechanisms which merit greater scrutiny by criminologists. With the seepage of extraordinary powers into other areas of the criminal law, the lines between crime and the more politicized terrain 
of the 'emergency' become blurred, thereby problematizing analyses which tend to rely on this binary.

\section{Forms of Contagion in France}

The legal literature on 'contagion', 'transplantation' or the transfer of counterterrorist laws to other areas, has burgeoned since 9/11 (Donohue, 2008, 2009, 2012; Gross, 2003, 2006; McGarrity et al., 2010), drawing on an earlier body of work examining the impact of the Northern Irish conflict on criminal justice systems either side of the border (Hillyard, 1983, 1993; Kilcommins and Vaughan, 2004; Vaughan and Kilcommins, 2008; Walsh, 1989). The categories outlined below are therefore informed by this literature, particularly the work of Laura Donohue (2012) who through her typology of 'transplantation' has probably done most to attempt to outline the contours of the phenomenon. While the three categories outlined below form distinct groupings in terms of their effects on the criminal law and other areas, they are not, however, rigid. As will be discussed further, sometimes two or more forms of contagion may combine and overlap, thereby working together to further entrench counterterrorist law in the mainstream system (Donohue, 2009: 378).

\section{Use of terrorism as a 'picklock'}

It barely needs stating that the 'politics of fear' (Kostakopoulou, 2008: 321) ensuing in the period following the commission of a terrorist attack may also represent something of a 'window of opportunity' for governments with the heat of the emergency providing convenient political cover for previously controversial legislative measures. Den Boer (2006), for example, has questioned whether the 9/11 attacks were used by the European Union as a means of legitimizing the rapid adoption of highly contentious measures and technologies of security governance (Hassan, 2010). Walker (2006: 1143) has made similar observations in respect of the United Kingdom's response to the Twin Tower attacks, describing the legislation as 'opportunistic changes that would not have been sustained outside a period of crisis'. Even outside of the reaction-politics engendered by a terrorist attack, criminologists have observed the use of serious crimes such as organized crime and terrorism as a 'picklock' for the introduction of controversial legislation that would otherwise be obstructed (Fijnaut and Paoli, 2004: 5; see also Cesoni, 2007). Significantly, these authors have also observed that since the $9 / 11$ attacks terrorism has begun to replace organized crime in the extension and consolidation of the droit d'exception (exceptional law).

In the French context perhaps the best example of the potential of terrorism to leverage broader reforms is the Intelligence Act of 24 July 2015. Dubbed the 'French Patriot Act' (Chardel et al., 2016), the Act provides for mass surveillance techniques for the purpose inter alia of preventing terrorism and was the first legislative response after the Charlie Hebdo attack of 7 January 2015. Given the sweeping nature of the provisions contained within the Act, the International Federation of Human Rights (FIDH) has claimed that the attack 'legitimised a law that would have certainly been difficult to get approved' (FIDH, 2016: 27). Certainly, the context of the attacks provided a convenient 
cover for the introduction of legislation that served to legalize - and extend - highly intrusive surveillance that was already being carried out illegally by intelligence services. Launched in 2008, France's large-scale internet surveillance programme lacked a valid legal basis, prompting calls for a new legal framework and expanded powers to collect metadata (Chardel et al., 2016; Tréguer, 2017). The subsequent Snowden revelations in 2013, however, made the introduction of legislation regulating surveillance 'politically risky and unpredictable' (Tréguer, 2017: 17) and it was only with the Paris attacks of January 2015 that the opportunity arose for the passage of the controversial legislation.

The main provisions of the Act include the possibility for intelligence agencies to access data retained by internet and telephone service providers and to conduct, for terrorism prevention purposes, real-time analysis of electronic metadata relating to a person 'previously identified as a threat'. ${ }^{1}$ The Act controversially replaces the judicial authorization previously needed for tapping of phones and emails with administrative oversight by the Prime Minister after seeking the (non-binding) views of a new body, the National Committee of Intelligence Techniques Control (FIDH, 2016; Hellmuth, 2015). This lack of independent oversight has been heavily criticized by Amnesty International (2015), among others, 'as a major blow to human rights' with many questioning the compliance of the legislation with European law (Cahn, 2016). From the instant perspective, however, the main issue concerns the scope of the Act which was presented as a counterterrorism tool but actually goes far beyond this to incorporate seven other situations where intelligence powers can be invoked (FIDH, 2016). Besides the prevention of terrorism, surveillance measures can be authorized for a wide range of purposes including: the protection of economic or overarching foreign policy interests; the prevention of 'collective violence constituting a serious threat to public order'; and 'organized criminality'. All of these grounds have been criticized by the Commission Nationale Consultative des Droits de l'Homme (CNCDH, 2015) for their lack of legal precision, amid fears that this would in practice lead to (among other things) systematic and widespread surveillance of social movements. Even leaving aside claims that the Act provides 'carte blanche for mass data interception' (Amnesty International, 2017), it is difficult to disagree with FIDH (2016: 28) that the expansion of the grounds for authorizing intelligence collection 'amounts to the generalisation of an exceptional - and highly objectionable - system of derogations that legalise large-scale surveillance'.

An earlier example of this form of contagion dates back to the initial legislative response to the 9/11 attacks, which in France came largely in the form of amendments to a pre-existing bill on 'daily security'. ${ }^{2}$ This bill was heavily amended after 11 September but not resubmitted to either the Conseil Constitutionnel (Constitutional Council) or Conseil d'Etat (Council of State) despite criticisms by human rights associations (Oehmichen, 2009). As observed by the CNCDH (2001) this lack of scrutiny was particularly unfortunate given that the amendments to the bill - which primarily aimed to prevent terrorism by targeting its financing - also contained provisions of more general application modifying sensitive provisions of the Code of Criminal Procedure. For instance, art. 24 of the Act extended the possibility to carry out house searches at night during preliminary investigations (excluding places of residence) in respect of not only terrorism, but also offences relating to weapons and drug trafficking. Notably, this 
provision had been proposed as far back as 1996 but had been censured by the Conseil Constitutionnel as a provision which excessively interfered with liberty rights. Of similarly general application is art. 23 of the Act granting powers to search moving or parked cars in the case of an investigation on terrorism, but also on offences related to arms, explosives and drug offences, including mere possession (Oehmichen, 2009). The scope of these provisions was criticized by the CNCDH (2001: 2), which argued that the use of such exceptional provisions in respect of offences such as the possession of narcotic drugs does not appear to be justified ('irrespective of their intrinsic seriousness, drug offences are not necessarily related to the financing of terrorist activities'). In 2003, Law no. 2003-239 of 18 March 2003 on Internal Security further extended these powers to the offences of theft and receiving stolen goods, despite the objections of the CNCDH (2002) that this amounted to a 'generalization' of police powers (Oehmichen, 2009). The net effect of this amendment was that vehicle searches were authorized for purely preventive purposes (art. 78-2-4), without the need for probable cause or warrants (only judicial requisition orders), again contravening earlier jurisprudence of the Conseil Constitutionnel (Dagron, 2004). The potential for discriminatory application of these types of stop and search provisions of this nature is clear ${ }^{3}$ and it is perhaps unsurprising to note reports in The Economist (2002) that the new powers on vehicle searches had been used 'mainly to police drug offences'. The effect is further compounded by powers enshrined in the legislation permitting the use of incriminating evidence found during these searches in subsequent, unrelated criminal proceedings (CNCDH, 2001).

\section{'Blank cheque' legislation}

A related, yet distinct, form of contagion can be identified as that deriving from counterterrorism provisions specifically aimed at terrorism and its related offences, yet broadly drafted and therefore susceptible to abuse. While equally pertaining to what Donohue (2012: 71) terms 'a lack of specificity in the initial statutory authorities' this type of contagion does not seek to apply exceptional security provisions to areas unrelated to terrorism, but rather to target terrorism and terrorist-related behaviour through broadly drawn ('blank cheque') legislation (Donohue, 2012: 71). The contagion - to non-terrorist crimes - thus occurs in the implementation phase although it is a direct consequence of the drafting process (Donohue, 2008). One of the best-known examples of this type of contagion in Britain is perhaps the use of section 44 of the Terrorism Act 2000, which introduced powers to stop and search without the need for any prior suspicion in areas where it was considered 'expedient' for the prevention of acts of terrorism, and which has been used extensively against protestors, journalists and civilians (Fenwick and Phillipson, 2011). Indeed, by the time of its amendment under ss. 59-62 of the Protection of Freedoms Act 2012, following a challenge in the European Court of Human Rights, hundreds of thousands of searches had been carried out under this provision without any recorded convictions for terrorism (Hodgson, 2013).

The broad drafting of terrorism and terrorism-related offences has a long history in France, with one of the key weapons in the French counter-terrorist arsenal being the illdefined criminal conspiracy or 'association de malfaiteurs' offence (De Villepin, 2006). This offence, introduced in 1996, took the controversial step of autonomously 
criminalizing participation in a criminal group in relation to terrorism but at a very early stage in the iter criminalis, namely, membership of a group 'established for the purpose of preparation, characterized by one or more material facts'. It has been severely criticized for its affront to principles of legal certainty as well as the very low thresholds of evidence for establishing participation in such a network (Cahn, 2010; Hodgson, 2013; Human Rights Watch, 2008). As one French judge, interviewed by Human Rights Watch (2008: 23) for its report on French counterterrorism, candidly observed: '[y]ou send people to prison in counterterrorism matters for very weak reasons. There was usually some kind of evidence, but of what? You had numbers in cell phones, trips, intense religiousness, consultation of certain websites.' Despite the very wide net cast by this offence, its 'success' in terms of securing convictions for terrorism offences has consolidated and extended a trend towards pre-emption in subsequent French legislation (Bonelli, 2008; Human Rights Watch, 2008). Among the long list of ancillary criminal offences enacted since 2001 are those criminalizing: an inability to justify one's lifestyle while being in regular contact with persons engaged in acts of terrorism; recruitment to participate in an association de malfaiteurs or acts of terrorism; provoking acts of terrorism and the promotion of terrorist acts; engaging in an individual terrorist enterprise; dissemination of data which justify or provoke acts of terrorism; and the regular consultation of websites which endorse acts of terrorism (Cahn, 2016). This 'highly inventive policy of incrimination'(Mayaud, 2013) clearly criminalizes offences of opinion or acts preparatory to a preparatory act, thereby pushing out the boundaries of the criminal law and the criminal justice 'net' (Cahn, 2016). In terms of the law's application, it would appear that it is the offence of 'apology of terrorism', introduced by act 2014-1353 of 13 November 2014, which has been relied on most heavily by prosecutors. In the first year of its application, the 2014 Act had been used to prosecute 700 individuals which 'in many cases did not constitute incitement to violence and thus $\mathrm{f}[\mathrm{e}] \mathrm{ll}$ within the scope of legitimate exercise of freedom of expression' (Amnesty International, 2016: 33). In the fortnight following the attacks in Paris in January 2015 alone, there were 298 judicial procedures for 'apology for terrorism', with numbers rising to 570 in the period following the November 2015 attacks (Amnesty International, 2017: 40).

Perhaps the most egregious example of broadly drafted legislation which has been applied outside of the counterterrorism field is the legislation establishing the state of emergency itself. On the night of the attacks of 13 November 2015 in Paris, the then President, François Hollande, declared a state of emergency, originally provided for in a 1955 law adopted to deal with the situation in Algeria, thereby granting powers to law enforcement bodies to conduct warrantless house searches, order house arrests and ban demonstrations. Despite the obvious connection with terrorism as the trigger for the current state of emergency powers (as included in derogation notifications to the UN and Council of Europe), the courts have endorsed an interpretation of the provisions of the 1955 Act that permits their use in other contexts. Following legal challenges taken to orders for house arrest placed on 26 environmental activists during the 2015 United Nations Conference on Climate Change in Paris, the Conseil d'Etat, France's highest administrative body, upheld the government's views that this did not constitute a disproportionate interference with the freedom to come and go. ${ }^{4}$ Other abusive applications of the emergency powers included bans issued against labour law protestors and measures 
taken within the framework of the state of emergency to control illegal immigration (Amnesty International, 2015, 2016, 2017; CNCDH, 2016).

Of further concern are reports detailing the application of these powers to the ordinary criminal sphere and particularly offences related to drugs. In line with previous legislation extending the use of counterterrorist powers to drugs offences, FIDH (2016: 19) reports that most of the searches authorized by the Prefecture (local authority) under the state of emergency were carried out by members of the drugs squad, in an effort to 'boost the number of searches conducted and opportunistically issue search orders for persons linked to ordinary crimes by claiming the existence of a direct link between drug trafficking and terrorism'. These claims, by members of the Union Syndicale des Magistrats (USM), are supported by the statistics from the Ministry of the Interior which reveal that out of the 576 legal proceedings opened on foot of the over 4000 searches carried out under the state of emergency only six have been initiated by the specialist national antiterrorist unit (CNCDH, 2016). The majority of these measures have instead been used to institute proceedings in the ordinary courts relating to possession of weapons, drugs trafficking or apology of terrorism.

\section{The 'new normal'}

In this final category we return to more familiar arguments concerning the role of counterterrorism legislation in diluting core procedural safeguards (Zedner, 2007b). The inclusion in counterterrorism legislation of exceptional measures limiting procedural rights means that courts are often called upon to address constitutionality concerns and to approve constitutional limits on policing, especially when the provisions are broadly or vaguely worded. However, as observed by Stuntz (2002), such limits are also transubstantive, in that they are not limited to terrorist suspects but rather apply equally to all suspects. When a court approves derogations from procedural safeguards in the name of security, such derogations become equally applicable outside the counterterrorism domain, creating a new constitutional or legislative template, and thereby becoming 'the new normalcy' (Donohue, 2009; Kilcommins and Vaughan, 2004; Stuntz, 2002; Vaughan and Kilcommins, 2008). Important here also is the bureaucratic tendency to return to old law and order solutions to the extent that governments reconfigure the problem to match the solutions they have already prepared (Bigo, 2002; Cahn, 2010). By becoming the yardstick against which legislators and the public measure their ability to counteract other serious crime, powers previously described as 'extraordinary' or even 'draconian' become part of the everyday administration of justice (Cobane, 2003; Hillyard, 1987; Kilcommins and Vaughan, 2004). In the French context, what Cahn (2010: 487) describes as the 'hegemonic tendency' of counter-terrorist legislation is particularly evident and will be examined here in two main ways: first, the extension of the procedural rules created in the counterterrorist context to organized crime, and second, the introduction into the ordinary criminal law of measures inspired by the state of emergency regime.

The existence in France since 1986 of a parallel criminal procedure or criminal procedure bis, comprising a series of special procedural rules and diluted procedural safeguards for terrorist crimes, has undoubtedly greatly increased the risk of normalization (Lazerges, 2003). As in other jurisdictions, the extension of special measures is most 
likely to occur in relation to other serious crimes, particularly organized crime, ${ }^{5}$ and it is therefore unsurprising to observe in the French criminal justice system an almost 'reciprocal' relation between the two areas, 'with exceptions in one sphere, seamlessly applying to the other' (Hodgson, 2013: 17). Following the introduction of wider police powers to search vehicles and residences in the 2001 and 2003 Acts - which, as already noted, applied to both terrorist, weapons and drugs offences - the ultimate fusion between organized crime and terrorism occurred with Act 2004-204 of 9 March 2004 (Cahn, 2010; Hodgson, 2013). The Act, whose stated aim was to adapt justice to the evolution of criminality, introduced the offence of organized crime not by defining it as such, but rather through the simple listing of 19 qualifying offences, terrorism being the 11 th in the list (Oehmichen, 2009). Criminal acts ranging from murder to theft can thus be categorized as organized crime when they are committed in a criminal group (bande organisée), 'established for the preparation of one or more offences, characterized by one or more material acts'. Most significantly, the Act applied the procedural tools that were originally confined to terrorist offences to this wider range of crimes, among them an array of covert surveillance measures, powers to conduct night searches in places of residence, an extended period of detention (96 hours) and delayed access to a lawyer. While the ostensible aims of the Act were to adapt the justice system to new forms of crime in general, there is little doubt that the origins of the legislation lie in the 'special zone' constructed by counterterrorist laws enacted since 1986. Indeed, it is telling that, in justifying the new 96 hour detention period to the Assemblee Nationale, the government stressed that the Act merely extends existing custody periods to the most serious forms of crime (Warsmann, 2003). This becomes particularly problematic when the sheer scope of application of the law is considered. Referred to by the CNCDH (2016: 18) as, 'vast, fluctuating and inconsistent', the highly fluid nature of the definition of organized crime in France means that, as Hodgson (2013: 18) notes, '[a] group of boys who come together in order to steal another boy's bus pass would fall within [it]'.

After the paths of terrorism and organized crime formally crossed in 2004, the conceptual fusion of the two concepts continued, further increasing the likelihood of contagion. Thus, in the wake of the November 2015 attacks on Paris, the government announced:

the need to adapt legislative provisions on organised crime and, more specifically, on terrorism in order to strengthen in a long-term way the tools and resources available to the administrative and judicial authorities, beyond the temporary legal framework that is in place under the state of emergency. (FIDH, 2016: 29, emphasis added)

The ensuing legislation, Act 2016-731 of 3 June 2016, can be viewed as perpetuating the construction of a permanent exceptional criminal procedure that began with the 2004 Act (Cahn, 2016). The Act further expanded the inventory of organized crimes by adding several offences relating to weapons, explosives and financial crime. Significantly, the Act extended to police and the prosecutors investigating organized crimes and other serious offences (including terrorism) the controversial new surveillance powers granted to intelligence services in the July 2015 Act. Thus, prosecuting authorities can now gain access, remotely and without the suspect's knowledge, to electronic communication data 
protected by username/password once it is judicially authorized. Indeed, in emergency situations, 'arising from an imminent risk of loss of evidence or serious harm to persons or property' electronic surveillance technology can now be deployed without prior judicial approval (although an ex-post judicial authorization after a maximum of 24 hours is still required) (International Commission of Jurists, 2016). Thus, powers initially justified as a proportionate and necessary response to a terrorist emergency (the Charlie Hebdo attacks) have now come to be 'judicialized', to borrow Cahn's (2016) term, with, as he further observes, important knock-on effects for the distinction between intelligence services/the police and intelligence/evidence.

The June 2016 Act is also interesting from another perspective, namely the institutionalization of state of emergency measures and their transposition into the ordinary, permanent criminal justice system. Several such measures can be identified, namely assigned residency/house arrest and powers to search residences (CNCDH, 2016). In relation to orders for house arrest, these are aimed at individuals travelling to or from a 'terrorist theatre of operation' like Syria or Iraq and have been justified by the French government in terms of the need to exercise control over individuals who have thus far been able to avoid criminal prosecution, namely Muslim women (FIDH, 2016). The 2016 provisions permit house arrest for up to one month upon return to France with a variety of restrictions such as reporting requirements. As with the assigned residency orders authorized under the state of emergency regime, they are imposed by the administrative authorities (subject only to judicial review a posteriori), on a much lower standard of proof than required under the existing Criminal Code, with stiff penalties of up to three years in the event of breach (Amnesty International, 2016; CNCDH, 2016). In placing these powers on a permanent footing the path has no doubt been cleared by the earlier decision of the Conseil Constitutionnel on the state of emergency measures to the effect that house arrest does not comprise a deprivation of liberty provided it does not exceed 12 hours day. ${ }^{6}$

The provision on house searches, regulated by the 1955 Act, was amended by the November act 2015-1501 extending the state of emergency to allow night searches without prior judicial authorization in the case of threat to public security and order, and in any case in which 'there are serious grounds for believing that the place is frequented by a person whose behaviour constitutes a threat to public security and order' (art. 4 of act 2015-1501). The June 2016 Act permanently allowed night searches during preliminary investigations of terrorist offences in the event of an 'emergency' ('to prevent the risk of harm to life or physical integrity') whereas the existing Criminal Code allowed night searches only in the case of the main (flagrant) investigation or in the immediate risk of concealment or destruction of evidence (art. 706-90 of the Criminal Procedural Code). Again, what is notable about the new provisions is their interchangeability with the state of emergency measures; indeed Lacaze (2017) directly links the dropping of the night search powers from the May 2016 extension of the state of emergency to the enactment of this more permanent provision.

\section{Criminology and Counterterrorism a la Française}

Fifteen years ago, Didier Bigo (2002) expressed his concern that terrorism could be used as a 'catch-all category' in France justifying repressive policies in areas beyond terrorism 
and thus giving rise to a 'routinization' of exceptional procedures. As Cahn (2010) has written, his words have proved highly prescient in terms of French criminal justice reform post 9/11. Beginning with the initial response to the 9/11 attacks, enhanced powers to search vehicles and residences, previously declared unconstitutional, were introduced by the government. As with subsequent reforms, provisions have been included permitting the use of evidence discovered relating to other offences in subsequent proceedings, something which is not without significance given wider impact of these powers and the possibility of knowing abusive use of derogatory procedures (CNCDH, 2001). Taken together with other examples such as the Intelligence Act 2015, we may wonder, with Cahn (2016), FIDH (2016) and other commentators (Lazerges and HenrionStoffel, 2016), about the utility of terrorism as a means of justifying broader reforms. As has also been observed, exceptional powers, accrued as part of the fight against terror, are consistently applied to 'related' crimes such as drugs and weapons offences, despite the absence of any obvious link with minor offences such as possession of drugs. This trend, again evident since 2001, was consolidated with the 2004 Act applying counterterrorist powers to organized crime more broadly, including minor forms of delinquency. More recently, it has been continued, not only with the steady accretion of new offences under the organized crime banner, but with the 'opportunistic' application of state of emergency search powers to drugs and weapons offences to now form the majority of prosecutions resulting from the state of emergency measures (CNCDH, 2016; FIDH, 2016).

Both normatively and practically, therefore, these new prerogatives are highly significant. As a conversation with any practising criminal lawyer will reveal, drugs offences form the 'bread and butter' of a criminal law practice in most jurisdictions (Kutateladze, 2009). Combined with the heavy use of the offence of 'apology for terrorism' these initiatives provide a broad array of legal tools for the discipline and control of young people from Muslim communities, particularly Maghrebis in low-income communities (Fassin, 2016). While apology for terrorism is prosecuted in the ordinary courts and therefore subject to ordinary investigation methods, it is nevertheless processed very quickly, requiring a person's 'immediate appearance' before a judge and also triggering the use of a number of special techniques for surveillance, infiltration and interception (Amnesty International, 2017; Lacaze, 2015). Amnesty International (2017) provide several examples of prosecutions brought for this offence against young Muslims in France, including those based on comments that young people have posted on Facebook and minor acts of graffiti.

On a normative level, offences related to terrorism have arguably spearheaded a trend towards pre-emptive criminalization in France with the autonomous criminalization, particularly since 2001, of highly equivocal acts 'preparatory to the preparation' for the offence (CNCDH, 2014). Linked with this is the significant increase in preventive powers, such as those of house arrest, being given to administrative authorities at the expense of the traditional law enforcement bodies (CNCDH, 2016). While the concern accompanying these trends, as in other jurisdictions, is the emergence of a parallel criminal procedure without the requisite procedural safeguards, in France this blurring of roles is particularly significant given the strict separation between the administrative police (charged with upholding public order) and the judicial police (charged with the investigation of crimes) and the constitutional protection given to same. Even more concerning 
is the emerging scholarly debate - prompted by both the steady expansion of the list of organized crimes attracting special measures and the exemption of the offence of apology of terrorism from the protections of the criminal law code for the press - of the possible 'eviction' of the ordinary criminal law in favour of a droit d'exception (Lazerges and Henrion-Stoffel, 2016; Mayaud, 2013). Gloomy though such prognoses may be, they serve to underline the serious implications of counterterrorist legislation and policy for the direction of travel of the criminal law in general. Unfortunately, moreover, these trends show no sign of slowing down with recent plans for a new bill ending the state of emergency but incorporating or 'repackaging' several state of emergency provisions into ordinary administrative and criminal law (Le Monde, 2017).

But is France a special case, an exception when it comes to states of exceptions (if one will forgive the tautology)? As already observed, the existence since 1986 of a special category of offences derogating from the common law or criminal law bis has no doubt helped accelerate the process of contagion in France. This much was heavily stressed by interviewees and, indeed, is perhaps to be expected in a jurisdiction which has purposefully sought to disrupt potential terrorism-crime linkages (Hellmuth, 2015). Yet it would be misleading not to acknowledge the existence of these trends elsewhere. The prolific use of suspicionless stop and search powers in the UK (until 2012) has already been noted, and this has been accompanied by concerns about the spread of the special advocate procedure to other areas of the criminal law (Fenwick and Phillipson, 2011) as well as the abuse of surveillance powers to monitor minor criminal activity such as dog fouling (Longstaff and Graham, 2008). In Poland, another country included in the current study, recent counterterrorist legislation concerning 'terrorism' and 'terrorist incidents' has been drafted so broadly and with such a lack of imprecision that Amnesty International has called into serious question the connection of the examples provided (e.g. loss of a passport abroad) with terrorist activity (Amnesty International, 2017: 25). Even beyond the instant study, comparative accounts from countries such as Norway (Husabø, 2013) and Australia (Ananian-Welsh and Williams, 2015; Appleby and Williams, 2010) are quickly accumulating detailing the substantial impact of counterterrorist legislation on the criminal justice system more broadly.

While far from suggesting that contagion is inevitable the above account nevertheless serves to raise questions about the complementarity between the ordinary criminal law and the counterterrorism field. Writing in the early days of the 'war on terror', Zedner (2007a, 2007b) was quick to recognize the hegemonic power of terrorism and the securitization agenda more generally. In her later work important questions about the transformative potential of terrorism for criminal law were posed: is there a danger it will be 'terrorized' (Zedner, 2014)? The above discussion outlining the variety of subtle ways in which the mainstream system is impacted occurs both substantiates this thesis and also prompts further criminological reflection on the connections, both normative and practical, being forged between 'exceptional' and 'ordinary' legal regimes. If, as Aradau and Van Munster (2009: 688, emphases added) contend, 'existing criminological interpretations show how exceptional politics overwrites the law', while for international relations it 'also underwrites the law', perhaps it is timely also to acknowledge the exception may become the law? All the more so in the context of a permanent 'war on terror', we may struggle to 'tell the dancer from the dance', and thus the ordinary business of criminal 
justice from its more politicized cousin (Kilcommins and Vaughan, 2004: 57). Looking to the French example again, for example, is it still correct to speak of France reserving the 'hard' face of its criminal law for terrorists while treating other criminals more leniently as observed by comparative scholars such as Whitman (2005: 127)? Is such a division sustainable, particularly in light of recent events? For how would a French criminologist credibly navigate the contemporary criminal realm in France without reference to the politics and policies of the emergency?

Better engagement with counterterrorism brings, as other authors have observed, both challenges and opportunities (Deflem, 2009). Challenges include the frequent absence, unlike with crime, of hard data on the actual implementation of counterterrorist legislation as well as the shroud of secrecy usually accompanying counterterrorist operations (see, for example, Lum et al., 2006). But opportunities also abound. First, as previously observed by Lennon (2015) in this journal, the substantial literature already accumulated within criminology on precautionary measures in the context of counterterrorism may also find an application in the counterterrorist activities of security and police organizations 'on the ground'. Because policing and prosecutorial bodies are inevitably targeted at the criminal components of terrorist incidents, their activities in terrorism-related activities are ideally suited for criminological analysis (Deflem, 2009). Second, connected as it is to broader debates on transformation in the penal field and the various political transformations which have gone before them, criminology remains well positioned to reflect on these developments (Loader, 2007). This vantage point is important for, as observed by both Donohue $(2012)$ and Lea $(2005,2015)$ a contagion effect is by no means one-way; just as important as 'trickle-down' is 'trickleup' where policies based on the strategies developed for surveillance and control of the poor in the ordinary criminal realm migrate (often inappropriately) to the counterterrorism field. While the obvious example in the UK is the ASBO and the control order, this is evident in France also with the inclusion as far back as 1994 in the ordinary criminal code of a range of offences criminalizing risky behaviour whose consequences in terms of harm were far from certain, or indeed probable (Lazerges and Henrion-Stoffel, 2016). In assessing such developments and their migration to the counterterrorist sphere (and back) the unique province of criminology is its ability to reconcile policies aimed at 21 st-century 'super-terrorism' (Lazarus and Goold, 2007) with the pursuit of security of a more anodyne kind. Indeed, it is perhaps in this more sociologically informed analysis that the beginnings of a process of social contestation of contagion and its associated effects may be found.

\section{Acknowledgements}

The authors would like to express their thanks to the Irish Research Council which generously funded this research through its New Horizons scheme. Sincere thanks also go to Barry Vaughan, Shane Kilcommins and the anonymous reviewers for their insightful comments on earlier drafts of this article.

\section{Declaration of Conflicting Interests}

The author(s) declared no potential conflicts of interest with respect to the research, authorship, and/or publication of this article. 


\section{Funding}

The author(s) disclosed receipt of the following financial support for the research, authorship, and /or publication of this article: This research was funded by the Irish Research Council's New Horizons scheme.

\section{Notes}

1. Art. 5.

2. Loi no. 2001-1062 du 15 novembre.

3. See, for example, the 2009 study of the Open Society Justice Initiative which found that Arabs and blacks in France were eight times more likely than whites to be stopped by police (New York Times, 3 October 2013).

4. Conseil d'Etat, decision no. 395009 of 11 December 2015.

5. See further Kilcommins and Vaughan (2004: 74) on the 'metaphoric pathways' which are often forged between terrorism and organized crime.

6. Conseil Constitutionnel, decision no. 2015-527 QPC of 22 December 2015.

\section{References}

Aas KF (2012) (In)security-at-a-distance: Rescaling justice, risk and warfare in a transnational age. Global Crime 13(4): 235-253.

Aas KF (2013) Globalization and Crime. Los Angeles, CA: SAGE.

Amnesty International (2015) L'état d'urgence a visé les défenseurs de l'environnement. Paris: Amnesty International.

Amnesty International (2016) Upturned lives: The disproportionate impact of France's state of emergency. London: Amnesty International.

Amnesty International (2017) Dangerously disproportionate: The ever-expanding national security state in Europe. London: Amnesty International.

Ananian-Welsh R and Williams G (2015) The new terrorists: The normalisation and spread of anti-terror laws in Australia. Melbourne University Law Review 38(2): 362-408.

Appleby G and Williams J (2010) The anti-terror creep: Law and order, the states and the high court in Australia. In: McGarrity N and Williams LN (eds) Counter-Terrorism and Beyond: The Culture of Law and Justice after 9/11. London: Routledge, 150-169.

Aradau C and Van Munster R (2009) Exceptionalism and the 'war on terror': Criminology meets international relations. British Journal of Criminology 49: 686-701.

Ashworth A and Zedner L (2014) Preventive Justice. Oxford: Oxford University Press.

Bigo D (2002) L'impact des mesures anti-terroristes sur l'équilibre entre liberté et sécurité et sur la cohésion sociale en France. In: Bribosia E and Weyembergh A (eds) La lutte contre le terrorisme et les droits fondamentaux. Nemesis, Bruylant, Coll. Droit et justice no. 34 .

Bonelli L (2008) Les caractéristiques de l'antiterrorisme français: 'Parer les coups plutôt que panser les plaies'. Le Monde, 11 September. Available at: http://www.lemonde.fr/societe/ article/2008/09/11/les-caracteristiques-de-1-antiterrorisme-francais-parer-les-coups-plutotque-panser-les-plaies_1093469_3224.html.

Cahn O (2010) The fight against terrorism and human rights: The French perspective. In: Wade M and Maljevic A (eds) A War on Terror? New York: Springer, 467-503.

Cahn O (2016) «Cet ennemi intérieur, nous devons le combattre». Le dispositif antiterroriste français, une manifestation du droit pénal de l'ennemi. Archives de Politique Criminelle 38: 91-121.

Cesoni ML (ed.) (2007) Nouvelles méthodes de lutte contre la criminalité. La normalisation de l'exception. Brussels: Bruylant. 
Chardel P-A, Harvey R and Volat H (2016) The French Intelligence Act: Resonances with the USA PATRIOT Act. Technology Science, 15 March. Available at: https://techscience. org/a/2016031501/.

CNCDH (2001) Avis sur les dispositions législatives proposées par le Gouvernement en vue de renforcer la lutte contre le terrorisme. Paris: Commission Nationale Consultative des Droits de l'Homme.

CNCDH (2002) Avis portant sur le projet de loi pour la sécurité intérieure. Paris: Commission Nationale Consultative des Droits de l'Homme.

CNCDH (2014) Avis sur le projet de loi renforçant les dispositions relatives à la lutte contre le terrorisme. Paris: Commission Nationale Consultative des Droits de l'Homme.

CNCDH (2015) Avis sur le projet de loi relatif au renseignement dans sa version enregistrée le ler avril 2015 à la Présidence de l'Assemblée nationale. Paris: Commission Nationale Consultative des Droits de l'Homme.

CNCDH (2016) Statement of opinion on the state of emergency. Paris: Commission Nationale Consultative des Droits de l'Homme.

Cobane C (2003) Terrorism and democracy: The balance between freedom and order: The British experience. $\mathrm{PhD}$ Thesis, University of Cincinnati, USA.

Dagron S (2004) Country report on France. In: Walter C, Vöneky S, Röben V, et al. (eds) Terrorism as a Challenge for National and International Law: Security versus Liberty? Berlin: Springer, 217-266.

Deflem M (2009) Terrorism. In: Miller MJ (ed.) 21st Century Criminology: A Reference Handbook. Los Angeles, CA: SAGE, 533-540.

Den Boer M (2006) Fusing the fragments: Challenges for EU internal security governance on terrorism. In: Mahncke D and Monar J (eds) International Terrorism: A European Answer to a Global Threat. Brussels: Peter Lang, 83-111.

De Villepin D (2006) Prevailing against terrorism. White paper on domestic security against terrorism. Paris: La documentation Française.

Donohue LK (2008) The Cost of Counterterrorism: Power, Politics, and Liberty. Cambridge: Cambridge University Press.

Donohue LK (2009) The perilous dialogue. Georgetown Public Law and Legal Theory Research Paper No. 12-028, Georgetown University.

Donohue LK (2012) Transplantation. In: Ramraj VV, Hor M, Roach K, et al. (eds) Global AntiTerrorism Law and Policy. Cambridge: Cambridge University Press, 67-87.

Economist, The (2002) For whom the Liberty Bell tolls. The Economist, London, 29 August. Available at: http://www.economist.com/node/1301751.

Ericson RV (2007) Crime in an Insecure World. London: Polity Press.

Fassin D (2016) Short cuts. London Review of Books 38(5): 23.

Fenwick H and Phillipson G (2011) Covert derogations and judicial deference: Redefining liberty and due process rights in counterterrorism law and beyond. McGill Law Journal 56(4): 863-918.

FIDH (2016) Counter-terrorism measures and human rights: When the exception becomes the norm. Paris: Fédération Internationale des Ligues des Droits de l'Homme.

Fijnaut C and Paoli L (eds) (2004) Organized Crime in Europe: Concepts, Patterns and Policies in the European Union and Beyond. Dordrecht: Springer.

Gross O (2003) Chaos and rules: Should responses to violent crises always be constitutional? Yale Law Journal 112(5): 1011-1134.

Gross O (2006) What 'emergency' regime? Constellations 13(1): 74-88.

Hassan O (2010) Constructing crises, (in)securitising terror: The punctuated evolution of EU counter-terror strategy. European Security 19(3): 445-466. 
Hellmuth D (2015) Countering jihadi terrorists and radicals the French way. Studies in Conflict \& Terrorism 38(12): 979-997.

Hillyard P (1983) Law and order. In: Darby J (ed.) Northern Ireland: The Background to the Conflict. Belfast: Appletree Press, 32-61.

Hillyard P (1987) The normalization of special powers: From Northern Ireland to Britain. In: Scraton P (ed.) Law, Order and the Authoritarian State. Milton Keynes: Open University Press, 279-312.

Hillyard P (1993) Suspect Community: People's Experiences of the Prevention of Terrorism Act in Britain. London: Pluto Press.

Hodgson JS (2013) Legitimacy and state responses to terrorism: The UK and France. Legal Studies Research Paper No. 2013-30, Warwick School of Law.

Human Rights Watch (2008) Preempting justice: Counterterrorism laws and procedures in France. New York: Human Rights Watch.

Husabø EJ (2013) Counterterrorism and the expansion of proactive police powers in the Nordic states. Journal of Scandinavian Studies in Criminology and Crime Prevention 14(1): 3-23.

International Commission of Jurists (2016) Bulletin: Counter-terrorism and human rights. European Human Rights Law Review EHRLR 347.

Kilcommins S and Vaughan B (2004) A perpetual state of emergency: Subverting the rule of law in Ireland. Cambrian Law Review 35: 55-80.

Kostakopoulou D (2008) How to do things with security post 9/11. Oxford Journal of Legal Studies 28(2): 317-342.

Kutateladze B (2009) Is America Really So Punitive? Exploring a Continuum of US State Criminal Justice Policies. New York: LFB Scholarly Publishing.

Lacaze M (2015) Latest developments in the repression and prevention of terrorism under French criminal law. Montesquieu Law Review (3).

Lacaze M (2017) State of emergency and criminal law. Montesquieu Law Review (5).

LaFree G and Freilich JD (eds) (2016) The Handbook of the Criminology of Terrorism. Chichester: Wiley-Blackwell.

Lazarus L and Goold BJ (2007) Security and human rights: The search for a language of reconciliation. In: Goold BJ and Lazarus L (eds) Security and Human Rights. Portland, OR: Hart Publishing, 1-24.

Lazerges C (2003) La dérive de la procédure pénale. Revue de science criminelle 644.

Lazerges C and Henrion-Stoffel H (2016) Chronique de politique criminelle: Le déclin du droit pénal: l'emergence d'une politique criminelle de l'ennemi. Revue de science criminelle et de droit pénal comparé (3): 649-661.

Lea J (2005) Terrorism, crime and the collapse of civil liberties. Lecture to Criminology Society at Middlesex University, April.

Lea $\mathbf{J}$ (2015) From the criminalisation of war to the militarisation of crime control. In: Walklate $\mathrm{S}$ and McGarry R (eds) Criminology and War: Transgressing the Borders. Abingdon: Routledge, 198-207.

Le Monde (2017) Le Sénat adopte le projet de loi antiterroriste en première lecture. Le Monde, 19 July. Available at: http:/www.lemonde.fr/societe/article/2017/07/19/le-senat-adopte-leprojet-de-loi-antiterroriste_5162154_3224.html.

Lennon G (2015) Precautionary tales: Suspicionless counter-terrorism stop and search. Criminology and Criminal Justice 15(1): 44-62.

Loader I (2007) The cultural lives of security and rights. In: Goold BJ and Lazarus L (eds) Security and Human Rights. Portland, OR: Hart Publishing, 27-44.

Loader I and Percy S (2012) Bringing the 'outside' in and the 'inside' out: Crossing the criminology/IR divide. Global Crime 13(4): 213-218. 
Longstaff A and Graham J (2008) Anti-terrorism and police powers: Should we be concerned? Criminal Justice Matters 73(1): 15-16.

Lum C, Kennedy LW and Sherley A (2006) Are counter-terrorism strategies effective? The results of the Campbell Systematic Review on Counter-Terrorism Evaluation Research. Journal of Experimental Criminology 2(4): 489-516.

McCulloch J and Pickering S (2009) Pre-crime and counter-terrorism: Imagining future crime in the 'war on terror'. British Journal of Criminology 49: 628-645.

McGarrity N, Lynch A and Williams G (eds) (2010) Counter-Terrorism and Beyond: The Culture of Law and Justice after 9/11. London: Routledge.

Mayaud Y (2013) La politique d'incrimination du terrorisme à la lumière de la législation récente. AJ Pénal 9.

Murphy CC (2012) EU Counter-Terrorism Law: Pre-emption and the Rule of Law. Oxford: Hart Publishing.

Mythen G and Walklate S (2006) Criminology and terrorism: Which thesis? Risk society or governmentality? British Journal of Criminology 46(3): 379-398.

Oehmichen A (2009) Terrorism and anti-terror legislation - the terrorised legislator? A comparison of counter-terrorism legislation and its implications on human rights in the legal systems of the United Kingdom, Spain, Germany, and France. Leiden: Leiden University.

Shapiro J (2010) French responses to terrorism: From the Algerian war to the present. In: Crenshaw M (ed.) The Consequences of Counterterrorism. New York: Russell Sage Foundation.

Stuntz WJ (2002) Local policing after the terror. Yale Law Journal 111: 2137-2194.

Tréguer F (2017) Intelligence reform and the Snowden Paradox: The case of France. Media and Communication 5(1): 17-28.

Vaughan B and Kilcommins S (2008) Terrorism, Rights and the Rule of Law: Negotiating Justice in Ireland. London: Routledge.

Walker C (2006) Clamping down on terrorism in the United Kingdom. Journal of International Criminal Justice 4(5): 1137-1151.

Walklate S and Mythen G (2014) Contradictions of Terrorism: Security, Risk and Resilience. London: Routledge.

Walsh DPJ (1989) The impact of the antisubversive laws on police powers and practices in Ireland: The silent erosion of individual freedom. Modern criminal procedure: A comparative law symposium. Temple Law Review 62: 1099-1130.

Warsmann J-L (2003) Rapport fait au nom de la Commission des Lois Constitutionnelles, de la Législations et de l'Administration Générale de la République sur le Project de Loi (no. 784), portant adaptation de la justice aux évolutions de la criminalité. Paris: Assemblée Nationale.

Whitman JQ (2005) Harsh Justice: Criminal Punishment and the Widening Divide between America and Europe. Oxford: Oxford University Press.

Zedner L (2007a) Pre-crime and post-criminology? Theoretical Criminology 11(2): 261-281.

Zedner L (2007b) Preventive justice or pre-punishment? The case of control orders. Current Legal Problems 60(1): 174-203.

Zedner L (2014) Terrorizing criminal law. Criminal Law and Philosophy 8(1): 99-121.

\section{Author biographies}

Claire Hamilton, LL.B. (Ling. Franc.), BL, M. Litt., PhD, MA, PG Diploma in Human Rights Law is a senior lecturer in Law in the Department of Law, Maynooth University, Ireland. Her research and teaching interests include punitiveness, comparative penology and counterterrorism.

Giulia Berlusconi is a lecturer in Criminology in the Department of Sociology at the University of Surrey. Her research interests include: co-offending networks; social network analysis; counterterrorism; organized crime; drug markets. 